\title{
METODE CERTAINTY FACTOR DALAM PENERAPAN SISTEM PAKAR DIAGNOSA PENYAKIT ANAK
}

\author{
Dina Maulina ${ }^{1)}$, Asih Murti Wulanningsih ${ }^{2)}$ \\ ${ }^{1)}$ Manajemen Informatika ${ }^{2}$ Sistem Informasi \\ Fakultas Ilmu Komputer, Universitas Amikom Yogyakarta, \\ email: dina.m@ amikom.ac.id ${ }^{1)}, \underline{\text { asihmurtiw@gmail.com }}^{2)}$,
}

\begin{abstract}
Abstraksi
Penerapan sistem pakar untuk mendiagnosa penyakit anak dengan metode ketidakpastian yaitu Certainty Factor (CF) dimulai dengan merancang sistem berdasarkan akuisisi pengetahuan yang didapat dari dokter ahli anak, kemudian dilanjutkan dengan membangun basis pengetahuan dan memberikan nilai CF pada setiap gejala yang terkait dengan suatu penyakit anak dengan memberi rentang nilai 0 dan 1 . Pengguna sistem dapat memilih gejala penyakit yang dilihat dan dirasakan yang telah disediakan pada sistem dan selanjutnya sistem dapat mendiagnosa penyakit anak tersebut dan menampilkan penyakit yang memiliki gejala yang sama dengan cara pengurutan descending, dimana nilai terbesarlah yang merupakan hasil keputusannya. Pembuatan sistem pakar berbasis web ini dibangun menggunakan Framework Codeigniter. Dari hasil pengujian sistem didapatkan tingkat keakuratan penggunaan rumus CF dalalam implementasi mendiagnosa penyakit RFA (Rhinofaringtis Akut) adalah 95\%, penyakit GEA(Gastro Enteritis Akut) adalah 70\%, penyakit ISK (Innfeksi Saluran Kemih) adalah 70\%, penyakit Faringtis adalah 68\%, penyakit DM (Diabetes Melitus) adalah 50\%. Berdasarkan perhitungan manual program yang telah diimplementasikan dengan sistem ternyata metode Certainty Factor ini dapat memberikan hasil akurat yang diperoleh dari perhitungan berdasarkan bobot gejala yang dipilih pengguna pada sistem sekaligus dapat memberikan jawaban atas permasalahan yang tidak pasti kebenarannya seperti masalah pada penelitian ini yaitu diagnosa suatu penyakit.
\end{abstract}

Kata Kunci : Certainty Factor, Sistem Pakar, diagnosa, Penyakit Anak, Expert System

\begin{abstract}
The application of an expert system to diagnose childhood diseases with the uncertainty method, namely Certainty Factor (CF), begins by designing a system based on the acquisition of knowledge obtained from pediatricians, then proceed with building a knowledge base and giving a CF value for each symptom associated with a child's illness with give a range of values 0 and 1 . Users of the system can choose the symptoms of the disease seen and felt that has been provided in the system and then the system can diagnose the child's disease and display diseases that have the same symptoms by sorting descending, where the greatest value is the result of his decision. Making this web-based expert system was built using the Codeigniter Framework. From the results of system testing, the accuracy of the use of the CF formula in the implementation of diagnosing RFA (Acute Rhinopharyngeal Disease) is 95\%, GEA (Acute Gastro Enteritis) disease is 70\%, UTI (Urinary Tract Infection) is $70 \%$, Faringtis disease is 68\%, DM (Diabetes Mellitus) is 50\%. Based on the manual calculation of the program that has been implemented with the system it turns out that this Certainty Factor method can provide accurate results obtained from calculations based on the symptom weight chosen by the user at the same time can provide answers to problems that are uncertain as to the problem in this study, namely the diagnosis of a disease.Keywords: Certainty Factor, Expert System, diagnosis, Childhood Disease, Expert System
\end{abstract}

\section{Pendahuluan}

Anak sangat rentan dengan kuman penyakit dan berbagai macam penyakit bawaaan genotip dari orang tuanya. Ketakutan yang dirasakan orang tua adalah jika tidak tau gejala dan jenus penyakit yang diderita oleh anaknya sehingga akan lebih mempercayakan kepada pakar atau dokter ahli apabila terjadi gangguan kesehatan pada anak mereka agar dapat melakukan pencegahan lebih dini sebelum terjsdi sesuatu yang tidak diinginkan. Namun hal tersebut akan terkendala oleh jadwal praktek dokter yang terbatas dan harus mengantri karena banyaknya pasien. Berdasarkan masalah yang sering dijumpai tersebut maka penulis berinisiatif untuk membangun suatu aplikasi yang dibutuhkan sebagai alat bantu untuk mendiagnosa penyakit anak yang berupa sistem pakar.

Sistem pakar adalah salah satu cabang kecerdasan buatan atau artificial intelligence (AI) yang mempelajari cara mengadopsi pikiran dan 
nalar seorang pakar untuk menyelesaikan suatu permasahalan dan membuat suatu keputusan hingga pengambilan kesimpulan dari sejumlah fakta yang ada. Dasar dari sistem pakar yaitu bagaimana memindahkan pengetahuan yang dimiliki seorang pakar ke dalam komputer dan bagaimana menjadikan pengetahuan tersebut sebagai kesimpulan atau keputusan[1].

Tujuan dari penelitian ini adalah merancang suatu sistem pakar yang dapat digunakan untuk mendiagnosa suatu jenis penyakit anak berdasarkan gejala yang dirasakan user, sehingga user dapat menemukan solusi atau penanganan yang dihadapi menggunakan sistem pakar dengan metode certainty factor" yang dapat dikembangkan lebih lanjut dan memberikan kemudahan bagi pemakainya. Diharapkan penelitian ini dapat memberikan manfaat Untuk membantu bagi orang awam maupun pakar agar dapat melakukan penanganan lebih dini pada gangguan kesehatan anak dengan orang tua selaku user dapat menggunakan sistem ini untuk mengetahui jenis penyakit anak berdasarkan gejalagejala yang ada.

\section{Tinjauan Pustaka}

Referensi penelitian sebelumnya yang dijadikan sebagai acuan dalam penelitian ini antara lain:

Dina Maulina, Kusrini, Rudyanto Arief (2013), dengan penelitian yang berjudul "Pemodelan Sistem Pakar Analisis Karakter Anak Prasekolah Dengan Genre Musik". Sistem yan dibuat sudah bisa digunakan untuk menentukan kecenderungan jenis karakter anak berdasarkan nilai certainty factor (CF) yang dimasukkan oleh pakar pada menu ekspresi dan menu karakter. Kelemahan dari sistem belum bisa menampilkan gabungan dua karakter dalam hasil diagnosa. Hasil diagnosa hanya dapat menampilkan jenis karakternya dan prosentase kecenderungan karakter serta ciri-cirinya[2].

Hengki Tamando Sihotang (2014), dengan penelitian yang berjudul "Sistem Pakar Mendiagnosa Penyakit Kolesterol Pada Remaja Dengan Metode Certainty Factor (CF) Berbasis $W e b$ ". Dalam sistem ini prensentasi gejala penyakit kolestrol pada remaja memiliki 8 rule (aturan) diagnosa yang selanjutnya dilakukan basis pengetahuan untuk digunakan menentukan pasien menghidap penyakit kolestrol atau tidak. Lalu, pada penerapan Metode Certainty Factor (CF) dapat mempermudah dan memberikan perhitungan penyelesain seberapa pasti para user mengetahui penyakit kolestrol pada remaja[3].

Laila Septiana (2016), pada karyanya yang berjudul "Perancangan Sistem Pakar Diagnosa
ISPA Dengan Metode Certainty Factor Berbasis Android". Aplikasi yang dibangun dapat digunakan oleh pengguna untuk mendiagnosa penyakit Infeksi Saluran Pernafasan Atas (ISPA) sebelum melakukan pemeriksaan lebih lanjut ke dokter. Penerapan Certainty Factor sebagai metode untuk pengambilan kesimpulan akhir sudah sesuai dengan hasil perhitungan manual dan hasil yang diberikan oleh sistem. Proses akuisi pengetahuan yang dilakukan sudah cukup efektif, hal ini diperkuat dengan hasil evaluasi terhadap ketepatan output sistem, baik berdasarkan pakar ataupun user. Proses akuisi pengetahuan tidak mudah, karena terdapat berbagai macam kendala seperti masalah waktu, pengetahuan yang bersifat dalam, kesulitan yang dialami knowledge engineer dalam memahami pengetahuan dibidang kedokteran[4].

Ahmad Fauzi (2016), dengan judul "Penerapan Forward Chaining Dalam Sistem Pakar Untuk Mendiagnosis Penyakit Pada Anak". Dalam penelitian ini, sistem pakar diagnosis penyakit pada anak dirancang berdasarkan basis pengetahuan mengenai 7 jenis penyakit yang sering terjadi pada anak. Konsultasi dilakukan melalui user interface aplikasi sistem pakar dengan memilih gejala yang dirasakan. Teknik penalaran inferensi melakukan proses pengambilan kesimpulan berdasarkan fakta-fakta yang telah diinputkan untuk kemudian diputuskan jenis penyakitnya[5].

Certainty Factor didefinisikan sebagai berikut:

$\mathrm{CF}[\mathrm{h}, \mathrm{e}]=\mathrm{MB}[\mathrm{h}, \mathrm{e}]-\mathrm{MD}[\mathrm{h}, \mathrm{e}]$

Dengan:

$\mathbf{C F}[\mathbf{h}, \mathbf{e}]=$ Faktor kepastian

$\mathbf{M B}[\mathbf{h}, \mathbf{e}]=$ Ukuran kepercayaan terhadap hipotesis h, jika diberikan evidence e (antara 0 dan 1)

MD[h,e] = Ukuran ketidakpercayaan terhadap hipotesis $\mathrm{h}$, jika diberikan evidence $\mathrm{e}$ (antara 0 dan 1)

Rumus :

$C F=\frac{\mathrm{MB}(\mathrm{H}, \mathrm{E})-\mathrm{MD}(\mathrm{H}, \mathrm{E})}{1-\min [\mathrm{MB}(\mathrm{H}, \mathrm{E}), \mathrm{MD}(\mathrm{H}, \mathrm{E})]}$.

\section{Metode Penelitian}

Data penyakit dan penanganan yang direkomendasikan ditunjukkan pada tabel 1 berikut:

Tabel 1. Data Penyakit Anak

\begin{tabular}{|c|l|l|l|}
\hline No & $\begin{array}{l}\text { Kode } \\
\text { Penyakit }\end{array}$ & $\begin{array}{l}\text { Nama } \\
\text { Penyakit }\end{array}$ & Penanganan \\
\hline 1 & P01 & Dyspepsia & $\begin{array}{l}\text { Dyspepsia dikenal } \\
\text { juga sebagai keluhan } \\
\text { nyeri lambung atau } \\
\text { sakit maag. Berikut } \\
\text { cara penangannya : }\end{array}$ \\
\hline
\end{tabular}




\begin{tabular}{|c|c|c|c|}
\hline & & & 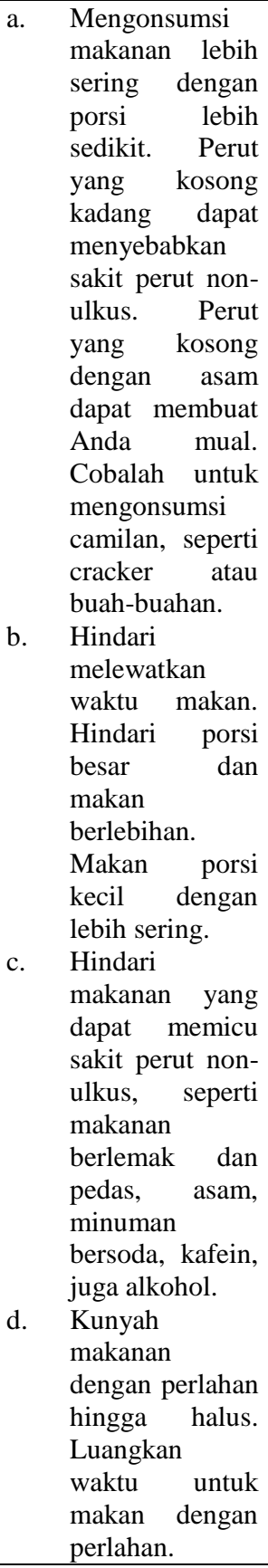 \\
\hline 2 & P02 & $\begin{array}{l}\text { ISPA } \\
\text { (Infeksi } \\
\text { Saluran } \\
\text { Pernafasan } \\
\text { Akut) }\end{array}$ & $\begin{array}{lr}\text { ISPA yaitu infeksi } \\
\text { yang terjadi pada } \\
\text { saluran pernapasan } \\
\text { yang dapat } \\
\text { menimbulkan gejala } \\
\text { batuk, pilek, disertai } \\
\text { demam. Penyakit ini } \\
\text { sangat r mudah } \\
\text { menular dan dapat } \\
\text { dialami siapa saja, } \\
\text { terutama pada anak- } \\
\text { anak.Berikut ini cara } \\
\text { penanganannya : } \\
\text { a. Usahakan waktu } \\
\text { tidur anak } \\
\text { cukup } \\
\text { b. Berikan banyak }\end{array}$ \\
\hline
\end{tabular}

\begin{tabular}{|c|c|c|c|}
\hline & & & 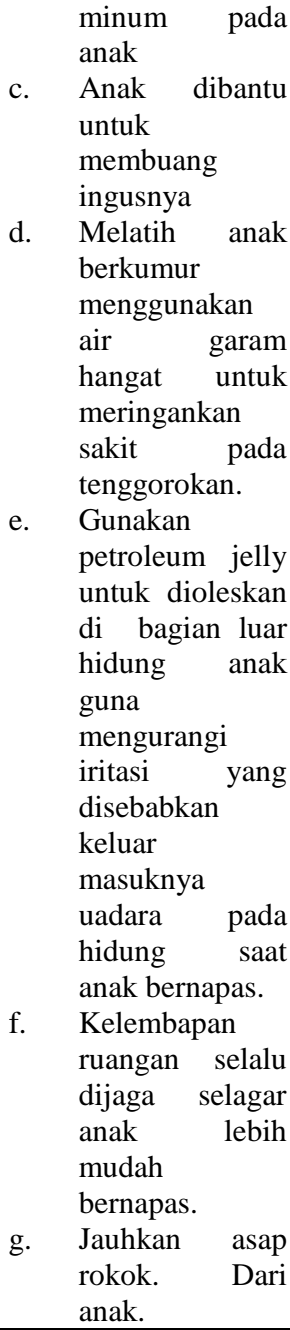 \\
\hline 3 & P03 & Gastritis & $\begin{array}{lr}\text { Gatritis } & \text { adalah } \\
\text { penyakit } & \text { pada } \\
\text { lambung } & \text { yang } \\
\text { disebabkan karenat } \\
\text { peradangan dinding } \\
\text { lambung. } \\
\text { penanganannya } \\
\text { adalah sara } \\
\text { berikut: } \\
\text { a. Hindari } \\
\text { makanan yang } \\
\text { pedas, yang } \\
\text { digoreng, } \\
\text { berlemak, dan } \\
\text { asam atau } \\
\text { bercuka. } \\
\text { bsahakan } \\
\text { makan dalam } \\
\text { porsi kecil tapi } \\
\text { sering, dan tidak } \\
\text { disarankan } \\
\text { langsung makan } \\
\text { besar 3 kali } \\
\text { sehari. } \\
\text { Usahakan } \\
\text { konsumsi } \\
\text { makanan yang } \\
\text { rendah }\end{array}$ \\
\hline
\end{tabular}




\begin{tabular}{|c|c|c|c|}
\hline & & & \begin{tabular}{lr} 
& \multicolumn{2}{l}{ untuk sementara } \\
& waktu supaya \\
& lambung tidak \\
bekerja terlalu & \\
keras. & \\
d. & $\begin{array}{l}\text { Diperbolehkan } \\
\text { konsumsi }\end{array}$ \\
& daging \\
berlemak & \\
misalnya dak & dada \\
ayam & atau \\
kalkun. &
\end{tabular} \\
\hline 4 & P04 & $\begin{array}{l}\text { RFA (Rhino } \\
\text { Faringtis } \\
\text { Akut) }\end{array}$ & $\begin{array}{l}\text { Rhinofaringtis adalah } \\
\text { salah satu jenis } \\
\text { penyakit yang mudah } \\
\text { menular lewat udara } \\
\text { yang disebabkan oleh } \\
\text { infeksi yang terjadi di } \\
\text { rongga hidung sampai } \\
\text { tenggorokan atau } \\
\text { faring. Berikut adalah } \\
\text { penanganannya : } \\
\text { a. Usahakan } \\
\text { banyak istirahat } \\
\text { b. Perbanyak } \\
\text { Minumair putih. } \\
\text { c. Makanlah } \\
\text { makanan yang } \\
\text { lunak dan } \\
\text { hangat. Gunakan larutan } \\
\text { d. garam untuk } \\
\text { berkumur. }\end{array}$ \\
\hline 5 & P05 & $\begin{array}{l}\text { DM } \\
\text { (Diabetes } \\
\text { Melitus) }\end{array}$ & $\begin{array}{l}\text { Diabetes Melitus } \\
\text { yaitu jenis penyakit } \\
\text { autoimun kronis yang } \\
\text { diakibatkan oleh } \\
\text { gangguan pengaturan } \\
\text { gula darah dalam } \\
\text { tubuh. Penyakit ini } \\
\text { biasa disebut juga } \\
\text { sebagai penyakit gula } \\
\text { atau kencing manis. } \\
\text { Berikut adalah } \\
\text { penanganannya : } \\
\text { a. Pertahankan } \\
\quad \text { berat badan } \\
\text { ideal Makan buah dan } \\
\text { b. Sayur } \\
\text { c. Kurangi } \\
\text { minuman manis } \\
\text { dan bersoda } \\
\text { e. Olahraga } \\
\text { Batasi gadget }\end{array}$ \\
\hline 6 & P06 & $\begin{array}{l}\text { GEA } \\
\text { (Gastro } \\
\text { Enteritis } \\
\text { Akut) }\end{array}$ & $\begin{array}{lr}\text { GEA } & \text { (Gastro } \\
\text { Enteritis Akut) atau } \\
\text { Diare yaitu buang air } \\
\text { besar tidak normal } \\
\text { ditandai tinja yang } \\
\text { encer dengan } \\
\text { frekuensi lebih sering } \\
\text { dari biasanya. Berikut } \\
\text { adalah rara }\end{array}$ \\
\hline
\end{tabular}

\begin{tabular}{|c|c|c|c|}
\hline & & & 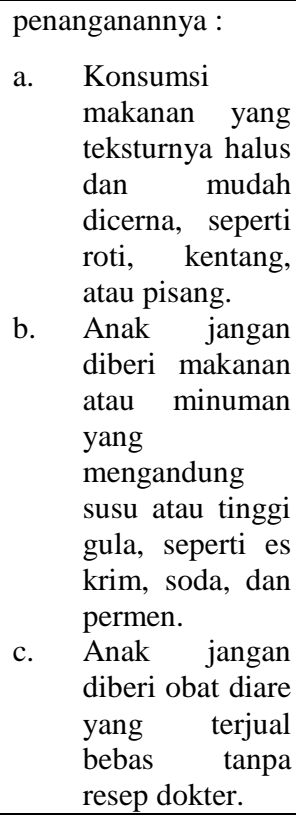 \\
\hline 7 & P07 & $\begin{array}{l}\text { VL (Vulnus } \\
\text { Laceratum) }\end{array}$ & $\begin{array}{l}\text { Vulnus Laceratum } \\
\text { (laserasi/robek) } \\
\text { adalah luka yang } \\
\text { disebabkan karena } \\
\text { benturan dengan } \\
\text { benda tumpul. Ciri - } \\
\text { ciri lukani adalah tepi } \\
\text { luka tidak rata dan } \\
\text { perdarahan sedikit } \\
\text { yang dapat } \\
\text { meningkatkan resiko } \\
\text { infeksi. Berikut ini } \\
\text { adalah cara } \\
\text { penanganannya : } \\
\text { a. Biasanya } \\
\text { perdarahan pada } \\
\text { goresan luka } \\
\text { ringan akan } \\
\text { berhenti sendiri. } \\
\text { Jika tidak } \\
\text { berhenti maka } \\
\text { beri tekanan } \\
\text { lembut pada } \\
\text { luka dengan } \\
\text { kain yang bersih } \\
\text { dan posisikan } \\
\text { luka menghadap } \\
\text { ke atas. } \\
\text { Gunakan air } \\
\text { bersih dan } \\
\text { mengalir untuk } \\
\text { membilas luka. } \\
\text { Boleh menggunakan } \\
\text { sabun untuk } \\
\text { member tapi } \\
\text { ihkan sekitar } \\
\text { luka tapi tidak } \\
\text { pada lukanya, } \\
\text { untuk menghindari } \\
\text { iritasi. }\end{array}$ \\
\hline
\end{tabular}




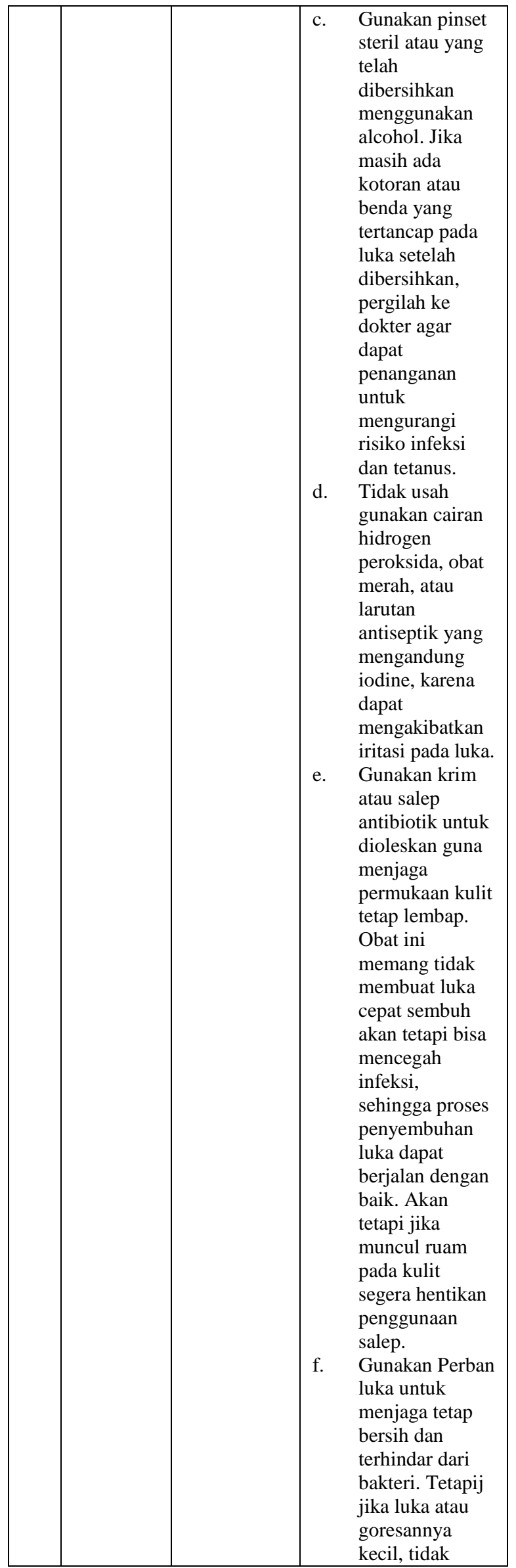

\begin{tabular}{|c|c|c|c|}
\hline & & & perlu diperban. \\
\hline 8 & P08 & Faringtis & $\begin{array}{ll}\text { Faringtis merupakan } \\
\text { suatu penyakit radang } \\
\text { tenggorokan. Cara } \\
\text { penanganannya } \\
\text { sebagai berikut : } \\
\text { a. } & \text { Konsumsi obat } \\
& \text { pereda nyeri } \\
& \text { yang dijual } \\
& \text { secara bebas, } \\
& \text { seperti } \\
& \text { paracetamol dan } \\
\text { ibuprofen, } & \\
\text { untuk } & \text { meredakan sakit } \\
\text { tenggorokan. } \\
\text { b. Perbanyak } \\
\text { istirahat. } \\
\text { Perbanyak } \\
\text { minum cairan } \\
\text { agar tidak } \\
\text { dehidrasi. } \\
\text { Gunakan } \\
\text { pelembab udara } \\
\text { di dalam } \\
\text { ruangan. } \\
\text { Konsumsi kaldu } \\
\text { hangat dan } \\
\text { minuman } \\
\text { dingin. } \\
\text { Kumurlah } \\
\text { menggunakan } \\
\text { air garam yang } \\
\text { hangat. } \\
\text { Makanlah } \\
\text { permen pelega } \\
\text { tenggorokan } \\
\text { untuk } \\
\text { meredakan } \\
\text { nyeri pada } \\
\text { tenggorokan. }\end{array}$ \\
\hline 9 & P09 & $\begin{array}{l}\text { ISK (Infeksi } \\
\text { Saluran } \\
\text { Kemih) }\end{array}$ & $\begin{array}{l}\text { Infeksi Saluran } \\
\text { Kemih terjadi pada } \\
\text { ginjal dan saluran } \\
\text { kemih. dan termasuk } \\
\text { penyakit yang sering } \\
\text { menyebabkan gagal } \\
\text { ginjal pada anak dan } \\
\text { mengakibatkan anak } \\
\text { membutuhkan } \\
\text { tindakan cuci darah } \\
\text { (dialisis) bahkan } \\
\text { cangkok ginjal } \\
\text { (transplantasi ginjal). } \\
\text { Berikut adalah cara } \\
\text { penaganannya : } \\
\text { a. Berilah obat } \\
\text { antibiotik } \\
\text { Anak didorong } \\
\text { untuk minum } \\
\text { banyak cairan, } \\
\text { tapi hindari } \\
\text { minuman yang } \\
\text { mengandung }\end{array}$ \\
\hline
\end{tabular}




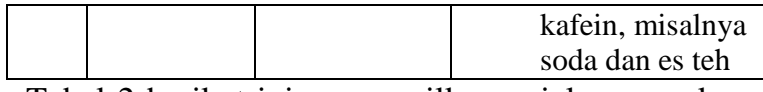

Tabel 2 berikut ini menampilkan gejala yang akan berelasi dengan data penyakit yang disesuaikan dengan data yang diambil dari seorang pakar .

Tabel 2. Data Gejala Penyakit Anak

\begin{tabular}{|c|c|c|}
\hline No & $\begin{array}{c}\text { Kode } \\
\text { Gejala }\end{array}$ & Nama Gejala \\
\hline 1 & G01 & Nyeri pada perut \\
\hline 2 & G02 & Perut terasa kembung \\
\hline 3 & G03 & Merasa tidak nyaman setelah makan \\
\hline 4 & G04 & Mual \\
\hline 5 & G05 & Muntah \\
\hline 6 & G06 & Tidak nafsu makan \\
\hline 7 & G07 & Terasa perih di perut atau dada \\
\hline 8 & G08 & Adanya makanan yang kembali ke atas \\
\hline 9 & G09 & Hidung tersumbat \\
\hline 10 & G10 & Batuk \\
\hline 11 & G11 & Bersin \\
\hline 12 & G12 & $\begin{array}{l}\begin{array}{l}\text { Produksi sputum atau dahak yang } \\
\text { berlebihan }\end{array} \\
\end{array}$ \\
\hline 13 & G13 & Demam \\
\hline 14 & G14 & Sakit kepala \\
\hline 15 & G15 & Kelelahan \\
\hline 16 & G16 & Merasa lemas \\
\hline 17 & G17 & Sakit saat menelan \\
\hline 18 & G18 & Suara serak \\
\hline 19 & G19 & $\begin{array}{l}\text { Perut bagian uluhati terasa panas dan } \\
\text { perih }\end{array}$ \\
\hline 20 & $\mathrm{G} 20$ & Perut terasa kembung \\
\hline 21 & $\mathrm{G} 21$ & Sering Cegukan \\
\hline 22 & G22 & Merasa cepat kenyang saat makan \\
\hline 23 & G23 & Tinja berwarna hitam \\
\hline 24 & $\mathrm{G} 24$ & Muntah darah \\
\hline 25 & G25 & Pilek \\
\hline 26 & G26 & Lemas \\
\hline 27 & G27 & Nyeri tenggorokan \\
\hline 28 & $\mathrm{G} 28$ & Banyak makan dan minum \\
\hline 29 & G29 & Sering buang air kecil \\
\hline 30 & G30 & Mudah mengompol \\
\hline 31 & G31 & $\begin{array}{l}\text { Penurunan berat badan yang drastis } \\
\text { dalam waktu 2-6 minggu sebelum } \\
\text { terdiagnosis }\end{array}$ \\
\hline 32 & G32 & Mudah marah \\
\hline 33 & G33 & Sesak napas \\
\hline
\end{tabular}

\begin{tabular}{|c|l|l|}
\hline 34 & G34 & Dehidrasi \\
\hline 35 & G35 & Menggigil \\
\hline 36 & G36 & Sakit perut \\
\hline 37 & G37 & Nyeri otot \\
\hline 38 & G38 & Nyeri sendi \\
\hline 39 & G39 & Luka robek pada kulit \\
\hline 40 & G40 & Berdarah \\
\hline 41 & G41 & Tenggorokan bengkak \\
\hline 42 & G42 & Badan terasa lelah \\
\hline 43 & G43 & Pusing \\
\hline 44 & G44 & Susah menelan \\
\hline 45 & G45 & $\begin{array}{l}\text { Saat kencing terasa nyeri, terbakar atau } \\
\text { ada sensasi menyengat }\end{array}$ \\
\hline 46 & G46 & Nyeri pada pinggul bagian belakang \\
\hline 47 & G47 & $\begin{array}{l}\text { Urin berbau busuk, terlihak keruh dan } \\
\text { mengandung darah }\end{array}$ \\
\hline
\end{tabular}

Kaidah produksi dalam mengidentifikasi gejala pada penyakit anak ditunjukkan pada tabel 3 berikut:

Tabel 3. Rule Sistem Pakar

\begin{tabular}{|c|c|}
\hline Rule 1 & $\begin{array}{l}\text { if } \mathrm{G} 01 \text { and } \mathrm{G} 02 \text { and } \mathrm{G} 03 \text { and } \mathrm{G} 04 \\
\text { and } \mathrm{G} 05 \text { and } \mathrm{G} 06 \text { and } \mathrm{G} 07 \text { and } \mathrm{G} 08 \\
\text { then } \mathrm{P} 01\end{array}$ \\
\hline Rule 2 & $\begin{array}{l}\text { if } G 09 \text { and } G 10 \text { and } G 11 \text { and } G 12 \\
\text { and } G 13 \text { and } G 14 \text { and } G 15 \text { and } G 16 \\
\text { and } G 17 \text { and } G 18 \\
\text { then } P 02\end{array}$ \\
\hline Rule 3 & $\begin{array}{l}\text { if } \mathrm{G} 04 \text { and } \mathrm{G} 05 \text { and } \mathrm{G} 06 \text { and } \mathrm{G} 19 \\
\text { and } \mathrm{G} 20 \text { and } \mathrm{G} 21 \text { and } \mathrm{G} 22 \text { and } \mathrm{G} 23 \\
\text { and } \mathrm{G} 24 \text { then } \mathrm{P} 03\end{array}$ \\
\hline Rule 4 & $\begin{array}{l}\text { if } G 09 \text { and } G 10 \text { and } G 13 \text { and } G 25 \\
\text { and } G 26 \text { and } G 27 \text { then P04 }\end{array}$ \\
\hline Rule 5 & $\begin{array}{l}\text { if } G 15 \text { and } G 28 \text { and } G 29 \text { and } G 30 \\
\text { and } G 31 \text { and } G 32 \text { and } G 33 \text { and } G 34 \\
\text { then } P 05\end{array}$ \\
\hline Rule 6 & $\begin{array}{l}\text { if } \mathrm{G} 04 \text { and } \mathrm{G} 06 \text { and } \mathrm{G} 13 \text { and } \mathrm{G} 14 \\
\text { and } \mathrm{G} 35 \text { and } \mathrm{G} 36 \text { and } \mathrm{G} 37 \text { and } \mathrm{G} 38 \\
\text { then } \mathrm{P} 06\end{array}$ \\
\hline Rule 7 & $\begin{array}{l}\text { If } \mathrm{G} 39 \text { and } \mathrm{G} 40 \\
\text { then } \mathrm{P} 07\end{array}$ \\
\hline Rule 8 & $\begin{array}{l}\text { if } G 04 \text { and } G 11 \text { and } G 13 \text { and } G 25 \\
\text { and } G 37 \text { and } G 41 \text { and } G 42 \text { and } G 43 \\
\text { and } G 44 \\
\text { then } P 08\end{array}$ \\
\hline Rule 9 & $\begin{array}{l}\text { if } \mathrm{G} 13 \text { and } \mathrm{G} 29 \text { and } \mathrm{G} 30 \text { and } \mathrm{G} 36 \\
\text { and } \mathrm{G} 45 \text { and } \mathrm{G} 46 \text { and } \mathrm{G} 37 \\
\text { then P09 }\end{array}$ \\
\hline
\end{tabular}


Proses diagnosa dilakukan untuk menentukan sebuah keputusan. Sistem akan menelusuri jenis penyakit berdasarkan gejala yang ada berdasarkan representasi pengetahuan dengan aturan kaidah produksi. Gambar 1 berikut gambar pohon keputusan :

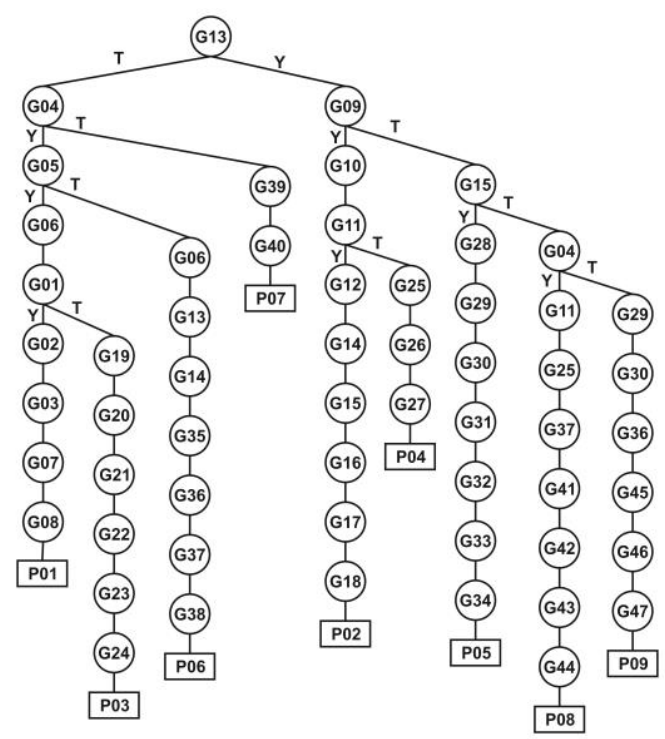

Gambar 1. Pohon Keputusan

Proses diagnosa suatu penyakit di sistem akan ditelusuri berdasarkan fakta atau gejala kemudian dicocokkan dengan rules berdasarkan metode certainty factor. Proses diagnosa sesuai gambar 2 berikut ini :

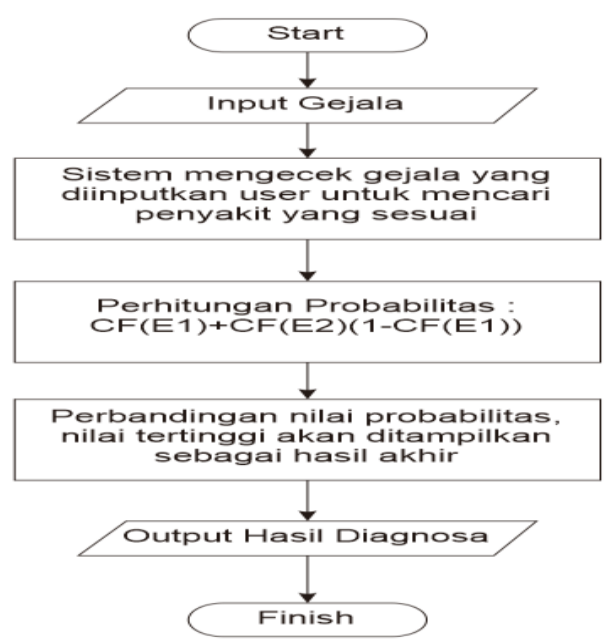

Gambar 2. Algoritma Diagnosa Sistem

Flowchart sistem merupakan sistematika untuk menggambarkan bagaimana jalannya program yang ditunjukkan pada gambar 3 berikut ini :

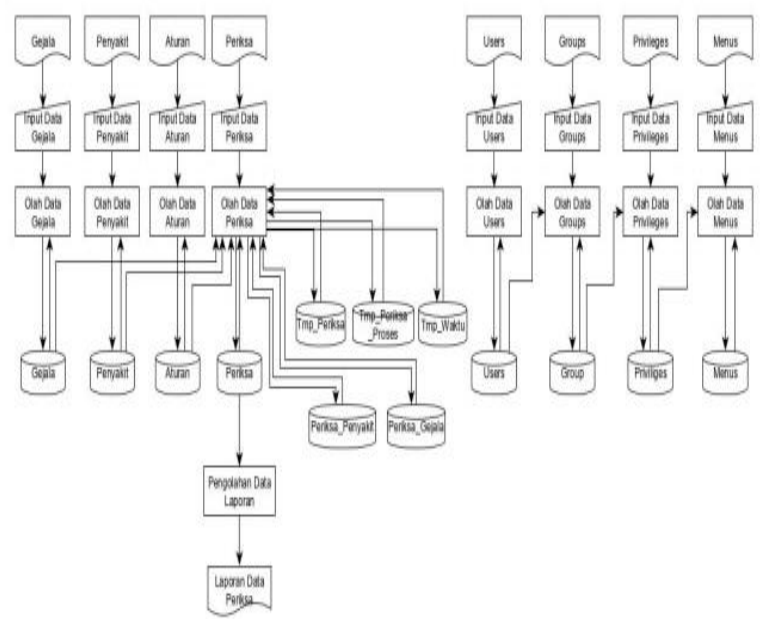

Gambar 3. Flowchart Sistem

Entity Realationship Diagram (ERD) yaitu diagram yang menunjukkan informasi yang akan dibuat dan disimpan untuk digunakan pada sistem. Atributnya dinyatakan sebagai field dari tabel-tabel tersebut [8]. Gambar 4 berikut adalah perancangan ERD yang akan dibuat :

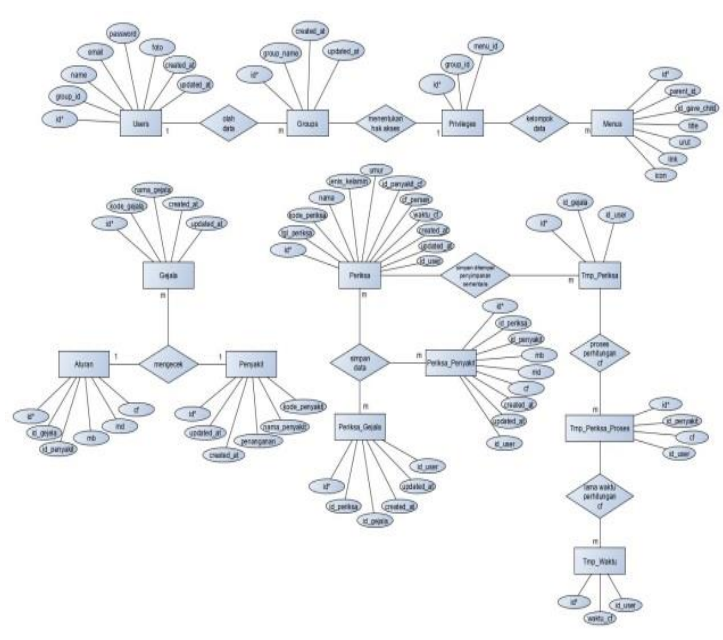

Gambar 4. Entity Realtionship Diagram (ERD)

\section{Hasil dan Pembahasan}

Tampilan Aplikasi sistem pakar menu diagnosa dan hasilnya terlihat pada gambar 5 dibawah ini, 


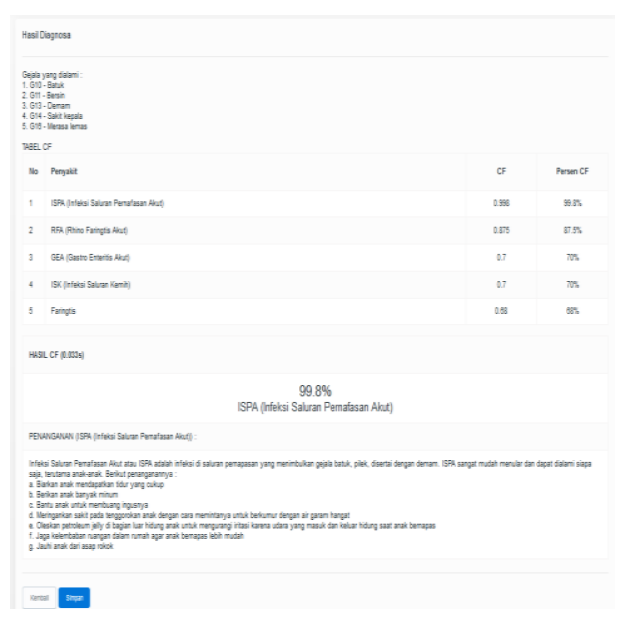

Gambar 5. Hasil Diagnosa Penyakit

Rumus Certainty factor adalah sebagai berikut :

$$
\begin{aligned}
& \mathrm{CFc}\left(C F_{1}, C F_{2}\right)= \\
& C F_{1}+C F_{2}\left(1-C F_{1}\right) \\
& C F_{1}+C F_{2}\left(1+C F_{1}\right) \\
& C F_{1}+C F_{2} /\left(1-\left(\left|C F_{1}\right|,\left|C F_{2}\right|\right)\right)
\end{aligned}
$$

Pada program yang dibuat penulis adalah menggunakan rumus pertama. Yaitu jika nilai $\mathrm{CF}$ bernilai > 0 atau positif, maka rumusnya sebagai berikut :

$$
C F_{1}+C F_{2}\left(1-C F_{1}\right)
$$

Berikut adalah contoh perhitungan manual program (menggunakan Rule 2) :

Tabel 4. Nilai CF Gejala pada Penyakit ISPA

\begin{tabular}{|l|l|l|l|}
\hline No & Gejala & Penyakit & CF \\
\hline 1 & Suara serak & ISPA & 0.4 \\
\hline 2 & Sakit saat menelan & ISPA & 0.3 \\
\hline 3 & Merasa lemas & ISPA & 0.5 \\
\hline 4 & Kelelahan & ISPA & 0.4 \\
\hline 5 & Sakit Kepala & ISPA & 0.6 \\
\hline 6 & Demam atau & ISPA & 0.5 \\
\hline 7 & $\begin{array}{l}\text { Produksi sputum } \\
\text { dahak yang berlebihan }\end{array}$ & ISPA & 0.6 \\
\hline 8 & Bersin & ISPA & 0.7 \\
\hline 9 & Batuk & ISPA & 0.8 \\
\hline 10 & Hidung tersumbat & & \\
\hline
\end{tabular}

Maka nilai CF Penyakit ISPA (Infeksi Saluran Pernafasan Akut) diperoleh dengan cara : $\mathrm{CF}(\mathrm{A})=\mathrm{CF}(1)+[\mathrm{CF}(2) *(1-\mathrm{CF}(1)]=0.4+[0.3$ $*(1-0.4)]=0.58$ $\mathrm{CF}(\mathrm{B})=\mathrm{CF}(3)+[\mathrm{CF}(\mathrm{A}) *(1-\mathrm{CF}(3)]=0.5+$ $[0.58 *(1-0.5)]=0.79$ $\mathrm{CF}(\mathrm{C})=\mathrm{CF}(4)+[\mathrm{CF}(\mathrm{B}) *(1-\mathrm{CF}(4)]=0.4+$ $[0.79 *(1-0.4)]=0.874$

$$
\begin{aligned}
& \mathrm{CF}(\mathrm{D})=\mathrm{CF}(5)+[\mathrm{CF}(\mathrm{C}) *(1-\mathrm{CF}(5)]=0.6+ \\
& {[0.874 *(1-0.6)]=0.9496} \\
& \mathrm{CF}(\mathrm{E})=\mathrm{CF}(6)+[\mathrm{CF}(\mathrm{D}) *(1-\mathrm{CF}(6)]=0.9+ \\
& {[0.9496 *(1-0.9)]=0.994} \\
& \mathrm{CF}(\mathrm{F})=\mathrm{CF}(7)+[\mathrm{CF}(\mathrm{E}) *(1-\mathrm{CF}(7)]=0.5+ \\
& {[0.994 *(1-0.5)]=0.997} \\
& \mathrm{CF}(\mathrm{G})=\mathrm{CF}(8)+[\mathrm{CF}(\mathrm{F}) *(1-\mathrm{CF}(8)]=0.6+ \\
& {[0.997 *(1-0.6)]=0.998} \\
& \mathrm{CF}(\mathrm{H})=\mathrm{CF}(9)+[\mathrm{CF}(\mathrm{G}) *(1-\mathrm{CF}(9)]=0.7+ \\
& {[0.998 *(1-0.7)]=0.999} \\
& \mathrm{CF}(\mathrm{I})=\mathrm{CF}(10)+[\mathrm{CF}(\mathrm{H}) *(1-\mathrm{CF}(10)]=0.8+ \\
& {[0.999 *(1-0.8)]=0.999}
\end{aligned}
$$

Sehingga CF penyakit ISPA (Infeksi Saluran Pernafasan Akut) adalah 0.999 (dibulatkan menjadi 1 atau $100 \%$ )

Kemudian, dari gejala yang telah diinputkan diturut dan dicek lagi berdasarkan penyakit yang memiliki gejala yang sama, lalu dilakukan nilai perhitungan CF-nya.

if both $>0$

Tabel 5. Nilai, if bothejala pada Penyakit RFA

\begin{tabular}{|l|l|l|l|}
\hline No & Gejala & Penyakit & CF \\
\hline 6 & Demam & RFA & 0.75 \\
\hline 9 & Batuk $\quad$ if both $>0$ & RFA & 0.5 \\
\hline 10 & Hidung tersumbat & RFA & 0.6 \\
\hline
\end{tabular}

Maka nilai CF Penyakit RFA (Rhinofaringtis Akut) diperoleh dengan cara sebagai berikut:

$\mathrm{CF}(\mathrm{A})=\mathrm{CF}(1)+[\mathrm{CF}(2) *(1-\mathrm{CF}(1)]=0.75+[0.5 *(1$ $-0.75)]=0.875$

$\mathrm{CF}(\mathrm{B})=\mathrm{CF}(3)+[\mathrm{CF}(\mathrm{A}) *(1-\mathrm{CF}(3)]=0.6+[0.875 *$ $(1-0.6)]=0.95$

Sehingga CF penyakit RFA (Rhinofaringtis Akut) adalah 0.95 (dibulatkan menjadi 0.95 atau $95 \%$ )

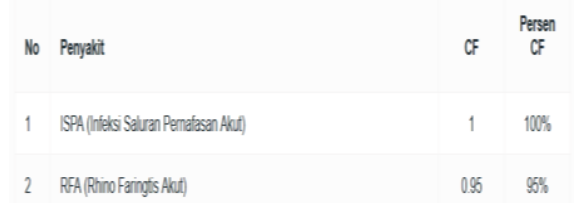

Gambar 7. Hasil nilai CF di pemrograman

Ketika dicek pada pemrograman, maka hasilnya sesuai dengan hasil perhitungan manual.

Diagnosa penyakit dyspepsia (P001).

Rule : if G01 and G02 and G03 and G04 and G05 and G06 and G07 and G08 then P01 


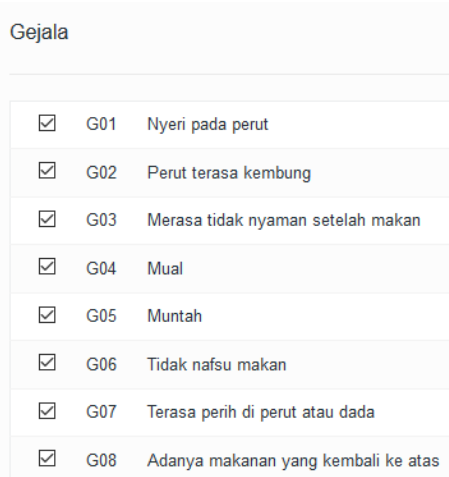

Gambar 8. Input Gejala Dyspepsia

\begin{tabular}{llcc} 
No & Penyakit & CF & $\begin{array}{c}\text { Persen } \\
\text { CF }\end{array}$ \\
1 & Dyspepsia & 0.999 & $99.9 \%$ \\
2 & Gastritis & 0.92 & $92 \%$ \\
3 & GEA (Gastro Enteritis Akut) & 0.4 & $40 \%$ \\
4 & Faringtis & 0.4 & $40 \%$ \\
HASIL CF (0.082s) & & \\
\hline
\end{tabular}

\section{$99.9 \%$ \\ Dyspepsia \\ PENANGANAN (Dyspepsia) \\ Dyspepsia dikenal juga sebagai keluhan nyeri lambung atau sakit maag. Berikut cara penangannya \\ a. Mengonsumsi makanan lebih sering dengan porsi lebih sedikit. Perut yang kosong kadang dapat menyebabkan sakit perut non-ulkus. Perut yang kosong dengan asam dapat membu \\ b. Hindari melewatkan waktu makan. Hindari porsi besar dan makan berlebihan. Makan porsi kecil dengan lebih sering. \\ c. Hindari makanan yang dapat memicu sakit perut non-ulkus, seperti makanan \\ Gambar 9.Hasil Diagnosa Penyakit Dyspepsia}

Pada tabel 6 berikut adalah perhitungan manual untuk menemukan hasil prosentase nilai Certainty Factor (CF) :

Tabel 6. Nilai CF Gejala pada Penyakit Dyspepsia

\begin{tabular}{|l|l|l|l|}
\hline No & Gejala & Penyakit & CF \\
\hline 1 & Nyeri pada perut & Dyspepsia & 0.7 \\
\hline 2 & Perut terasa kembung & Dyspepsia & 0.6 \\
\hline 3 & $\begin{array}{l}\text { Merasa tidak nyaman } \\
\text { setelah makan }\end{array}$ & Dyspepsia & 0.65 \\
\hline 4 & Mual & Dyspepsia & 0.5 \\
\hline 5 & Muntah & Dyspepsia & 0.4 \\
\hline 6 & Tidak nafsu makan & Dyspepsia & 0.5 \\
\hline 7 & $\begin{array}{l}\text { Terasa perih di perut } \\
\text { atau dada }\end{array}$ & Dyspepsia & 0.75 \\
\hline
\end{tabular}

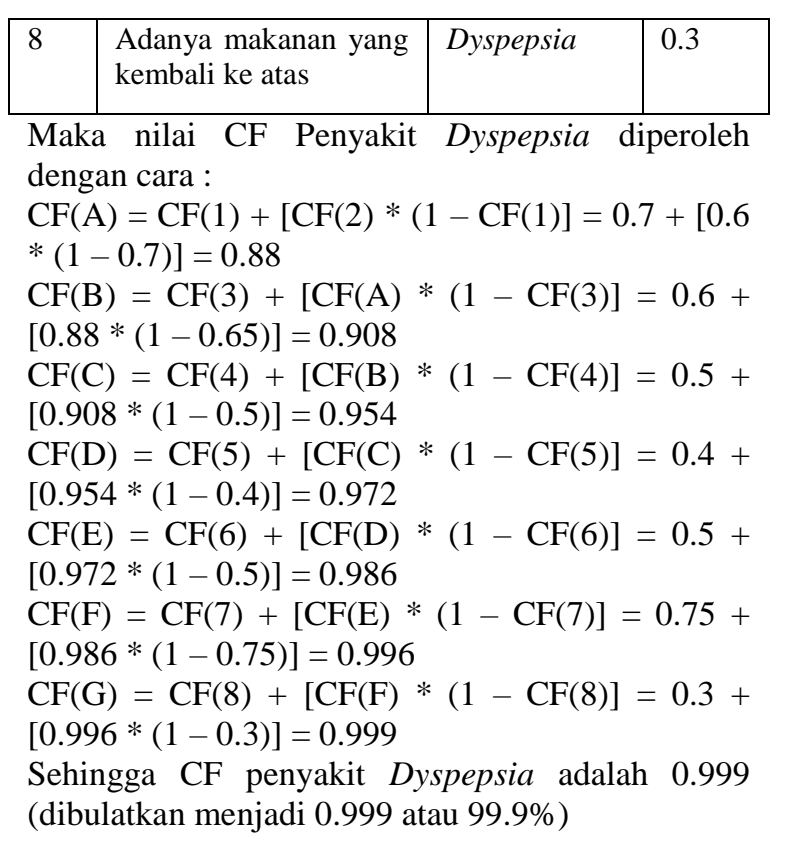

\section{Kesimpulan dan Saran}

Penyelesaian dari rumusan masalah pada penelitian ini didapatkan kesimpulan sebagai berikut:

1. Pembuatan sistem pakar untuk diagnosa penyakit anak berbasis web menggunakan Framework Codeigniter dengan metode yang diterapkan adalah Certainty Factor.

2. Sistem telah dapat menghasilkan informasi bagaimana cara menangani penyakit yang sedang dialami.

3. Basis pengetahuan telah dikembangkan secara dinamis, sehingga pembaharuan data gejala, penyakit dan aturan dapat dilakukan setiap saat jika diperlukan.

4. Pengguna dapat mencetak hasil diagnosa.

5. Berdasarkan pengujian hasil diagnosa sistem dengan pakar, hasilnya telah sesuai dengan pengetahuan pakar.

6. Berdasarkan perhitungan manual program dengan sistem, metode Certainty Factor ini mampu memberikan hasil berdasarkan bobot gejala yang telah dipilih pengguna pada sistem dan bisa memberikan jawaban pada kasus yang tidak pasti kebenarannya seperti masalah pada penelitian ini yaitu diagnosa suatu penyakit.

Dari penelitian yang dilakukan ini penulis memberikan saran untuk penyempurnaan pengembangan sistem ini selanjutnya antara lain sebagai berikut: 
1. Sistem pakar ini dapat dibuat menggunakan metode yang lain.

2. Jenis Penyakit bisa ditambah lebih banyak lagi untuk pengembangan sistem pakar ini.

3. Untuk penelitian selanjutnya dapat dikembangkan berbasis android.

\section{Daftar Pustaka}

[1] Sutojo. Kecerdasan Buatan. Yogyakarta : Andi Offset, 2011.

[2] Pemodelan Sistem Pakar Analisis Karakteristik Anak Prasekolah dengan Genre Musik. Maulina, D and Kusrini, Arif,R. 2013, SemnasTeknomedia.

[3] Sistem Pakar Mendiagnosa Penyakit Kolesterol pada Remaja dengan Metode Certainty Factor Berbasis Web. Sitohang, H.T. 2017, Mantik Penusa.
[4] Perancangan Sistem Pakar Diagnosa ISPA dengan Certainty Factor Berbasis Android. Septiana, L. 2016.

[5] Penerapan Foeward Chaining dalam Sistem Pakar untuk Mendiagnosa Penyakit pada Anak. Fauzi, A. 2016.

[6] Hayadi, B. Sistem Pakar. Yogyakarta : Deepublish, 2018.

[7] Pratiwi, H. Buku Ajar Sistem Pakar. Jawa Barat : Goresan Pena, 2019.

[8] Fatta, Hanif Al. Analisis dan Perancangan Sistem. Yogyakarta : Andi Offset, 2007. 